\title{
Roland Barthes's Semiotic Analysis: Islamic Anti-Radicalism Message to Raise Indonesia Reconciliation by Sukmawati Soekarnoputri
}

\author{
Dyah Ayu Nurindra ${ }^{1}$, Prahastiwi Utari ${ }^{2}$, Sudarmo $^{3}$ \\ ${ }^{123}$ Faculty of Social and Political Sciences, Sebelas Maret University, Surakarta, Indonesia \\ Jl. Ir. Sutami No.36A, Kentingan, Kec. Jebres, Kota Surakarta, Central Java 57126 \\ dyahnurindra@student.uns.ac.id ${ }^{1}$,prahastiwi@staff.uns.ac.id², sudarmo63@yahoo.com³
}

\begin{abstract}
Sukmawati Soekarnoputri is the daughter of Ir. Sukarno and also a humanist. She reaped the controversy after reading a poem entitled Ibu Indonesia and delivering her speech which alluded to the Prophet Muhammad and Ir. Sukarno. This study aims to find out the true meaning of Sukmawati's controversy. This research is a descriptive interpretative qualitative study. This paper uses the Roland Barthes's Semiotic analysis, which applies signifier and signified analysis to examine the sign denotative and to obtain connotative meaning. Therefore, the data are obtained from videos on YouTube. The result of this study shows that Sukmawati warns us about the dangers of Islamic radicalism in Indonesia. Besides, she advises us that it is important to remember the history of the heroes' struggle for the independence of Indonesia. She also mentions that there is only one ideology in Indonesia, namely Pancasila.
\end{abstract}

Keywords: Islamic Anti-Radicalism, Sukmawati, Roland Barthes

\section{Introduction}

The whole world certainly hopes for peace, but a conflict remains as one of the biggest threats to sustainable development. Every country has its ideology including Indonesia with its Pancasila, and every citizen must protect the ideology of his country. Indonesia has experienced many conflicts, both due to political and religious factors. However, lately, there many conflicts that have been caused by Islamic radicalism. In addition to threatening the ideology of Pancasila, Islamic radicalism has the potential to cause acts of violence for all parties deemed incompatible with this radical group. This reason is what underlies Sukmawati to express her unrest.

Diah Mutiara Sukmawati or commonly called Sukmawati Soekarnoputri is an artist and a politician born in Jakarta on October $26^{\text {th }}, 1951$. She was an alumnus of the Dance Academy at LPKJ in 1974[1]. Sukmawati Soekarnoputri had shocked the Indonesian people, especially those who are Muslim with two controversies that she made. The first controversy occurred at the 29-year of Anne Avantie career show at Indonesia Fashion Week in 2018. Sukmawati is a controversial humanist because of the diction she uses in her poem. Whereas, it is not unfamiliar that the authors of literary works can produce multiple interpretations with selected dictions to show their aesthetical value. As Zyngier said in Nurgiyantoro that it is important to emphasize the socio-cultural aspects, cultural factors, which are owned by the community to understand a style of literary work[2]. 
The second controversy happened at the public relation discussion of the Indonesian Police Force titled "Awaken Nationalism Together We Prevent Radicalism and Eradicate Terrorism" on November $11^{\text {th }}, 2019$. At that moment, Sukmawati compared the Prophet Muhammad to Soekarno. The speech she made can be possibly linked to Islamic radicalism in Indonesia. Sukmawati is a Muslim and she is the daughter of Ir. Soekarno and Mrs. Fatmawati. KH Hasan Din is Sukmawati's grandfather [3]. She wrote a historical testimony related to her life during her stay at Istana Merdeka (Presidential Palace). Her story is written in a book entitled Creeping Coup D'Tat Major General Suharto. In her book, she testified that Suharto had couped his father in 1965-1967. This evidence shows that Sukmawati is a figure who is very concerned about the history of the Indonesian nation.

Established as a secular state in 1945, Indonesia's constitution, known as Pancasila, states that all monotheistic religions must be respected [4]. However, that statement does not follow the fact that Islamic radicalism still exists. Radical Islamic movements in various forms are still widespread in almost all countries, including Indonesia. Evaluation, rejection, and resistance are a response to conditions that are happening called radicalism. Both in the form of radicalism in general and also Islamic radicalism will still exist. It is because of their strong belief in the ideological truth that they carry. One of the factors in the failure to eliminate radical understanding is the strong theological indoctrination of the leaders of the radical movement [5]. Radicalization refers to the interpretation and practice of Islam with maximum rigidity and intolerance towards alternatives [6]. In various aspects, the Islamic radicalism movement in Indonesia is firmly rooted in the early Islamist and jihadist thoughts of the Middle-Eastern connection [7]. By various explanations about radicalism, it can conclude that anti-Islamic radicalism is a sense of tolerance, mutual respect for fellow human beings, and not forcing opinions.

Radicalism in general and also Islamic radicalism will never stop [8]. The statement is indeed true with the holding of a virtual public discussion with the theme "Maintaining National Security Stability in the Middle of Covid-19". Maj. Gen. Rudianto, as the Deputy IV for National Defense, Coordinating Ministry for Political, Legal, and Security Affairs states that in the situation of the Covid-19 pandemic, the rumors of caliphate, radicalism, and terror still exist. Indeed, they are currently consolidating and preparing actions in the midst of this pandemic.

Caliphate system is often associated with radical movements. However, caliphate system clearly cannot be applied in Indonesia because Indonesia has Pancasila as its ideology. Many Civil Society Organizations (CSOs) use Islamic attributes and take part in the socio-economic and political sphere. It is not uncommon for such mass organizations to voice radical claims like the Indonesian Hizb ut-Tahrir (HTI). HTI triggered the caliphate movement in Indonesia, whose status of legal entity was revoked by the government in May 2018.

Roland Barthes (1915-1980) is one of the poststructuralist semiotics experts who developed Ferdinand de Saussure's Semiology through structural analysis [9]. Roland Barthes began to turn from his previous devotion to the structural theory and he explored some of the contradictions that still existed in the writing of de Saussure and Peirce in the late 1960s [10]. Connotation and denotation are the main things of Barthes's analysis. His idea is called two orders of signification. Barthes explains that this idea is originated from the existence of a relationship between signifier (expression) and signified (content) in a sign on an external phenomenon which is the significance of the first stage. Barthes calls this as denotation, where meaning is more real than sign. Connotative signs and two denotative signs that underlie their existence are showed Barthes's concept. In fact, Barthes's finding is an important contribution to the refinement of Saussure's semiology which stopped at the denotative level [11]. The 
denotation stage just looks at the sign language. We can examine the sign connotatively which is the cultural context from the understanding of language. The purpose of this paper is to discuss Sukmawati's poem and her controversial speech related to Islamic radicalism in Indonesia. The poem and speech are considered controversial because they are considered blaspheming Islam.

\section{Method}

This research is a qualitative research involving an interpretative and naturalistic approach to the world. Qualitative research studies objects in natural contexts and seeks to understand or interpret phenomena that are observed from the meanings attached to objects by researchers [12]. Therefore, this research seeks to gain knowledge or understanding of various interrelated relationships that occur behind the poetry and the controversial speech of Sukmawati Soekarnoputri with the reality that is happening in Indonesia. This research uses Sukmawati's poem and her statement in 2018 and 2019 as the research data. Data reduction, data presentation, and concluding are data analysis techniques. The data were obtained through observing YouTube videos about the reading of Sukmawati's poem in 2018 [13] and also the controversial speech of Sukmawati in 2019 [14]. The videos are observed audiovisually. This study uses data analysis in the form of a semiotic analysis concept that emphasizes the prominence of the framework of thought, perspectives, and concepts in order to interpret Sukmawati's controversial news. Roland Barthes's semiotic analysis is used in this study because the method has elements of research that are relevant to the research to be conducted. In addition, Roland Barthes's semiotic analysis has more complete instruments compared to other semiotic analysis methods. After Sukmawati's poem and controversial statement are analyzed, they will then be linked to the radical condition of Islam in Indonesia and also Sukmawati's background.

\section{Results And Discussion}

Roland Barthes's Semiotic Analysis. Sukmawati's poem was delivered by Sukmawati at the Indonesia Fashion Week 2018 with the title Ibu Indonesia. This poem discusses Islam and Indonesia. The analysis is presented as follows. At the beginning of the poem, the signifier is Aku tak tahu Syariat Islam. Yang ku tahu sari konde ibu Indonesia sangatlah indah. Lebih cantik dari cadar dirimu. (I do not know the Islamic sharia. What I know is that Indonesian mother bun is very beautiful. It is more beautiful than your burqa). The signified presented in this stanza is Sukmawati is standing on a stage, with a microphone in her right hand and a paper in her left hand. Sukmawati is wearing white kebaya with a brown shawl. The Indonesian flag is displayed on the screen become Sukmawati's background on the stage. Its denotative meaning shows Sukmawati admitting herself that she does not know Islamic law. She mentioned Ibu Indonesia as the personification of Indonesia. As we knew, Ibu Pertiwi is also commonly used as Indonesian's personification to describe an embodiment of the Indonesian homeland filled with its natural beauty and life. Besides clearly mentioning Islam, Sukmawati added the word burqa as an affirmation in her poem. Burqa is a piece of clothing commonly used by Muslim women to cover their faces, only leaving a space on their eyes. 
Her statement tries to convey the comparison custom of Indonesian women and Muslim women in general in term of dress. Sukmawati considers that Indonesian women appearance, with all its diversity, is more attractive than the appearance of Muslim women with burqa. We can conclude the poetry delivered by Sukmawati through Roland Barthes's semiotic analysis and then associate it with Indonesian culture so that we can get the connotative meaning. It means using burqa is not Indonesian culture. Most Muslims in Indonesia simply wear the hijab without the burqa, but this opinion is considered wrong by radical Islamists who require the use of the burqa. That is why not a few people associate burqa with radical Islam.

The second signifier says Gerai tekukan rambutnya suci. Sesuci kain pembungkus ujudmu (The bend in her hair is sacred. As sacred as the wrapper of your cloth). The signified in this line Sukmawati uses a bun and white kebaya completed with a brown shawl. The denotation is that Sukmawati uses the suffix -nya (hers) in the word rambut, which means an attribute of Indonesian women. She always stresses that the attributes of Indonesian women is no less beautiful than the attributes used by Muslim women. Then, the third signifier says Rasa ciptanya sangatlah beraneka. Menyatu dengan kodrat alam sekitar (The sense of its creation is very diverse. It blends with the power of surrounding nature). Sukmawati again uses the ownership word marker which refers to Indonesia. The connotation of this line means that Indonesia has created a lot of diversity such as ethnicity, religion, race, flora, and fauna. Menyatu dengan kodrat alam sekitar means that nature was created to be preserved. The diversity in Indonesia exists to complement each other. The more diverse a country is, the more beautiful it will be. Therefore, Indonesia with its diversity must be well guarded to avoid divisions caused by differences.

Jari jemarinya berbau getah hutan. Peluh tersentuh angin laut. (His fingers smells like forest sap. The sweats are touched by the sea breeze) is the fourth signifier. The signified is still the same. It shows Sukmawati wearing kebaya with a brown shawl, and occasionally directing her eyes to the audience. The ownership word marker, which still refers to Indonesia, has a connotation that Indonesia is rich in forests and seas. Many Indonesians depend their lives on these two sectors. Once again, she mentions Indonesia's natural diversity is very beautiful. Then, the fifth signifier says Lihatlah Ibu Indonesia. Saat pengelihatanmu semakin asing. Supaya kau dapat mengingat kecantikan asli dari bangsamu (Look at the mother earth of Indonesia. When your eyesight gets stranger. So you can remember the real beauty of your people with the signified which is still the same as the previous ones. The connotation is that when ideology is no longer the same as the ideology of Indonesia, we should remember all that Indonesia has been given to us. We should remember that God gives favors in the form of land that can support more than 200 million people in Indonesia. Indonesia's diversity certainly exists to strengthen the national unity, not to break down one another. History showed that Indonesian people was able to unite they fought for a freedom from the invaders.

The sixth signifier says Jika kau ingin menjadi cantik, sehat, berbudi, dan kreatif. Selamat datang di duniaku, bumi Ibu Indonesia (If you want to be beautiful, healthy, virtuous, and creative. Welcome to my world, The mother earth of Indonesia). The signified that supports these lines is the beautiful authentic Indonesian kebaya that she wears. The connotation is that everyone in Indonesia is free to create and express his creativity as long as it does not against the rules set out in the Unitary Republic of Indonesia. The next signifier is aku tak tahu syariat Islam. Yang ku tahu suara kidung Ibu Indonesia, sangatlah elok. Lebih merdu dari alunan azanmu (I don't know Islamic law. What I know is the the sound of Kidung of Indonesian mother earth, very beautiful. It is more melodious than the sound of your azan). Kidung is the authentic Javanese poetry while azan is a call for Muslims to pray. The label of the Islamic religion is once again raised where the word azan is mentioned. Sukmawati is comparing the 
sound of azan to the sound of Indonesian art of performing Kidung. The last signifier is Gemulai gerak tarinya adalah ibadah. Semurni irama puja kepada Ilahi (The graceful movement of its dance is worship. As sacred as the rhythm of worshiping God). These lines denote the way to express gratitude to God. Customary rituals that are still carried out by some Indonesian people, is an authentic way to express gratitude for the pleasure of fertile land. Even though Indonesia has determined its recognizable religions, it does not seem wise to judge the way people worshiping God.

Sukmawati Speech 2019. This speech was delivered by Sukmawati while she was attending the public relation discussion of the Indonesian Police Force with the theme "Awaken Nationalism Together We Prevent Radicalism and Eradicate Terrorism" on November $11^{\text {th }}, 2019$. There are three denotation meanings resulted from Sukmawati's speech. The explanation is presented as follows.

The first signifier says Yang berjuang di abad 20, itu Nabi yang Mulia Muhammad apa Ir. Soekarno untuk kemerdekaan (Who else was struggling for Indonesian independence in the 20th century. Is he Prophet Muhammad or Ir. Soekarno)". The signified is that she is standing on the podium and holding the microphone in her right hand. At that moment, Sukmawati shows an expression of firm tone. The denotation means that Sukmawati conveys the history of the Indonesia towards its independence with the involvement of the proclaimer. She instills the spirit of nationalism to the audience. Then, the second signifier is Ayo jawab gak ada yang berani. Saya mau yang laki-laki. Kan soalnya radikalis banyaknya laki-laki ya (Is anyone dare to answer? I want a male. Most of radical practitioners are male, aren't they?). The signified is that she is waiting and looking for someone to answer her question. The denotation is that it is okay for someone to respect a prophet, but he should not forget to respect the heroes who have fought for Indonesia's independence. The last signifier is that she questions whether it is forbidden to glorify people other than based on religious belief. He asserts that those who are meritorious have the right to be respected regardless of their religion. The signified is expressed through Sukmawati's tone which is always firm when she is talking.

Its correlation to Islamic radicalism. Sukmawati recited a poem at the 29 -year of Anne Avantie career show at Indonesia Fashion Week in 2018. Anne Avantie is a well-known female designer in Indonesia. In her poem, Sukmawati intends to declare that all Indonesian women have the right to be respected regardless of their ethnicity, religion and race. It's not wise to marginalize women of different beliefs. Whatever attributes used by Indonesian women, whether veiled or not, they deserve to be respected. God does not create differences to hurt or bring down one another. In addition, Sukmawati's speech in 2019 at the public relation discussion of the Indonesian Police Force is already in accordance with the topic which discusses about raising nationalism by counteracting radicalism and combating terrorism. On that occasion, Sukmawati reminds us to respect the struggle of Indonesian heroes in achieving independence. It is unfortunate if the independence that has been achieved for almost 75 years is being destroyed by those whose ideology is no longer the same as Pancasila. Sukmawati mentions that regardless of their gender, a person can be exposed to Islamic radicalism and can damage the harmony of the Republic of Indonesia.

Truly, Islam is a religion that provides security, comfort, tranquility and peace for all human beings. There is no Islamic teaching that teaches people to hate and hurt others, as well as other religions. Radical Islam is clearly not the reflection of true Islam. Islam is the largest religion in Indonesia. However, it is not surprising that there are few of its followers who are radical and intolerant. This phenomenon can be caused by many factors, one of which is due to political interest and authorization. 


\section{Conclusions}

Sukmawati is considered blasphemous to Islam due to her words. However, if the words are examined using Roland Barthes's semiotic analysis which includes dennotation and connotation, they can reveal its connotation meaning. Sukmawati states that Islamic radicalism that often unsettles Indonesian people tends to judge others wrong if they have different ideological views. In addition, they demand the establishment of an Islamic caliphate in Indonesia. In fact, it is very clear that caliphate system is highly irrelevant to Indonesia's diversity. Sukmawati reminds us to respect the struggle of the heroes to liberate Indonesia. It is unfortunate if Indonesia's diversity is undermined by individuals who consider their ideology to be the most correct one. It will be very dangerous if Islamic radicalism is being ignored. Radical groups will do everything they can to achieve their goals, including by performing acts of violence. Therefore, it is important to instill the spirit of nationalism in Indonesian society, especially the youths so that they will not be easily influenced by other ideologies aside Pancasila. Finally, toleration helps us to raise Indonesia reconciliation for sustainable development since every Indonesian citizen is guaranteed by law to choose religion and practice worship by following his religion and beliefs.

\section{References}

[1] "Sukmawati Soekarnoputri," viva.co.id, 2018. https://www.viva.co.id/siapa/read/807-sukmawatisoekarnoputri (accessed Jul. 17, 2020).

[2] T. Kamandanu, K. Linus, S. Pendekatan, S. Kultural, and B. Nurgiyantoro, "Penggunaan ungkapan jawa dalam kumpulan puisi," pp. 201-214, 1997.

[3] H. Darmayana, "Sukmawati Soekarnoputri Tak Mungkin Hina Nabi Muhammad," gesuri.id, 2019. https://www.gesuri.id/internal/sukmawati-soekarnoputri-tak-mungkin-hina-nabi-muhammadb1WpWZo9n (accessed Jul. 17, 2020).

[4] F. Syam, F. M. Mangunjaya, and A. R. Rahmanillah, "Narrative and the Politics of Identity: Patterns of the Spread and Acceptance of Radicalism and Terrorism in Indonesia," vol. 11, no. 6, 2020, doi: $10.3390 /$ rel1 1060290 .

[5] H. S. Zainiyati, "Curriculum, Islamic Understanding And Radical Islamic Movements In Indonesia," vol. 10, no. 02, pp. 285-308, 2016, doi: 10.15642/JIIS.2016.10.2.285-308.

[6] A. Sabic-el-rayess, "International Journal of Educational Development Epistemological shifts in knowledge and education in Islam : A new perspective on the emergence of radicalization amongst Muslims," Int. J. Educ. Dev., vol. 73, no. July 2019, p. 102148, 2020, doi: 10.1016/j.ijedudev.2019.102148.

[7] W. R. Jati, "Radicalism In The Perspective Of Islamic-Populism Trajectory of Political Islam in Indonesia Wasisto Raharjo Jati Indonesian Institute of Sciences, Jakarta - Indonesia," J. Indones. Islam, vol. 07, no. 02, pp. 268-287, 2013, doi: 10.15642/JIIS.2013.7.2.268-287.

[8] M. A. Wahid, "Fundamentalisme Dan Radikalisme Islam ( Telaah Kritis tentang Eksistensinya Masa Kini )," J. Wawasan Keislam., vol. 12, no. 1, pp. 61-75, 2018.

[9] A. Sobur, Analisis teks media: suatu pengantar untuk analisis wacana, analisis semiotik dan analisis framing. Bandung: Remaja Rosdakarya, 2009.

[10] L. Tredinnick, "Post-structuralism, hypertext, and the World Wide Web," Aslib Proc., vol. 59, no. 2, pp. 169-186, 2007, doi: 10.1108/00012530710736672.

[11] A. A. Syakur and M. Sukri, "Text of Cigarette Advertisement : A Semiology Study of Roland Barthes,” Int. J. Linguist. Lit. Cult., vol. 4, no. 3, pp. 72-79, 2018, doi: 10.21744/ijllc.v4n3.182.

[12] Y. S. Denzin, N. K., \& Lincoln, Handbook of qualitative research. Thousand Oaks, Sage Publications, 2002. 
[13] M. Custom, "VIRALL !! Kontroversi Puisi Sukmawati Soekarno Putri FULL Video," Youtube, 2018. https://www.youtube.com/watch?v=Mq0ROIVBkD0 (accessed Jul. 17, 2020).

[14] "Ini Pidato Sukmawati Bandingkan Nabi Muhammad dengan Sukarno," detik.com, 2019. https://www.youtube.com/watch?v=3rb4eAzJjD4 (accessed Jul. 11, 2020). 